\title{
Pengembangan Media Pembelajaran Multimedia Interaktif Pilar Baru (Pintar Belajar Bangun Ruang) pada Siswa Kelas VIII
}

\author{
Ismail $\mathrm{T}^{1, \mathrm{a})}$, Usman Mulbar ${ }^{1, \mathrm{~b})}$, dan Asdar ${ }^{1, \mathrm{c})}$ \\ ${ }^{1}$ Jurusan Matematika FMIPA Universitas Negeri Makassar, 90224

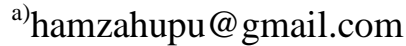 \\ b)u_mulbar@unm.ac.id \\ c)asdar_ahmad@unm.ac.id
}

\begin{abstract}
Abstrak. Penelitian pengembangan ini bertujuan untuk mengembangkan media pembelajaran multimedia interaktif Pilar Baru (Pintar Belajar Bangun Ruang) dan mendeskripsikan kualitas media berdasarkan aspek kevalidan, kepraktisan, dan keefektifan. Desain penelitian ini mengacu pada model pengembangan ADDIE yang meliputi 5 tahapan yaitu analysis, design, development, implementation, dan evaluation. Instrumen penelitian berupa lembar penilaian media oleh pakar materi, pakar media dan guru untuk mengukur kevalidan; angket respons dan lembar observasi keterlaksanaan pembelajaran untuk mengukur kepraktisan; serta soal tes hasil belajar untuk mengukur keefektifan media. Ujicoba produk dilakukan kepada 36 siswa kelas VIII. Hasil penelitian menunjukkan bahwa penilaian oleh pakar materi dan media diperoleh skor rata-rata 4,29 kemudian oleh guru diperoleh skor rata-rata 4,4 dengan kriteria sangat baik sehingga media yang dikembangkan dinyatakan valid. Hasil analisis data angket respons siswa diperoleh skor rata-rata 4,57 dan respons guru diperoleh skor rata-rata 4,62 dengan kriteria sangat baik. Hasil observasi keterlaksanaan pembelajaran menunjukkan klasifikasi sangat baik dengan persentase mencapai 96,87\%. Berdasarkan hal tersebut media dinyatakan praktis. Persentase ketuntasan klasikal dari tes hasil belajar siswa mencapai 80,6\% sehingga media dinyatakan efektif.
\end{abstract}

Kata kunci: pengembangan, multimedia interaktif.

\begin{abstract}
The purposes of this development research to develop interactive multimedia-based learning media Pilar Baru (Pintar Belajar Bangun Ruang) and describe the quality of media based on aspects of validity, practicality, and effectiveness. The design of this study refers to the ADDIE development model which includes 5 stages, namely analysis, design, development, implementation, and evaluation. The research instruments were in the form of media assessment sheets by material experts, media experts, and teachers to measure practicality. and learning outcomes test questions to measure media effectiveness. Product testing was conducted on 36 students of class VIII. The results showed that the assessment by the material and media experts was obtained an average score 4.29 then the teacher obtained an average score of 4.4 with very good criteria so that the developed media was declared valid. The results of the questionnaire response analysis of students obtained an average score of 4.57 and the teacher's response obtained an average score of 4.62 with very good criteria. The results of observations of the implementation of learning showed a very good classification with a percentage reaching $96.87 \%$. The percentage of classical completeness from student learning outcomes tests reached $80.6 \%$ so the media was declared effective.
\end{abstract}

Keyword: development, interactive multimedia

\section{PENDAHULUAN}

Geometri adalah salah satu materi yang susah dipahami oleh siswa. Hasil survey Programme for International Student Assessment (PISA) 2000/2001 menunjukkan bahwa siswa lemah dalam 
geometri khususnya dalam pemahaman ruang dan bentuk (Suwaji, 2008). Hal tersebut didukung oleh hasil penelitian yang dilakukan Madja (1992) menyebutkan bahwa prestasi belajar geometri siswa kurang memuaskan jika dibandingkan dengan materi matematika yang lain. Olehnya itu, dibutuhkan sebuah inovasi untuk mengatasi hal tersebut.

Salah satu upaya yang dapat diterapkan oleh guru di dalam kelas untuk meminimalisir kesulitan belajar matematika khususnya dalam bidang geometri adalah dengan memanfaatkan sarana dan prasarana pembelajaran, serta diperkaya oleh sumber belajar yang memadai seperti mefia pembelajaran. Penggunaan media pembelajaran dalam proses pembelajaran adalah salah satu upaya yang dapat dilakukan untuk meningkatkan kualitas hasil belajar dari siswa. Salah satu media pembelajaran yang dapat digunakan adalah multimedia interaktif.

Terdapat beberapa penelitian yang berkaitan dengan pengembangan media pembelajaran multimedia interaktif (Sansongko, 2018; Hendroanto, 2012; Fahmi, 2014; Priliyanti, 2012; dan Sanusi, Suprapto, \& Apriandi, 2015). Sassongko (2018) mengembangkan multimedia interaktif pada materi bangun datar. Adapun Hendroanto (2012) mengembangkan multimedia interaktif pada materi bangun ruang sisi datar.

Teknologi multimedia menggabungkan sepenuhnya teknologi komputer, sistem video, dan sistem audio untuk mendapatkan kombinasi dan meningkatkan interaksi pemakai dengan komputer. Tampilan dari multimedia menyediakan peluang bagi siswa untuk mengembangkan teknik pembelajaran sehingga menghasilkan hasil yang maksimal. Pembelajaran berbasis multimedia menggunakan perangkat multimedia sebagai sarana utama dalam hal ini komputer.

Penelitian ini berfokus pada pengembangan media pembelajaran multimedia interaktif yang diberi nama Pilar Baru (Pintar Belajar Bangun Ruang). Penelitian ini bertujuan untuk mengembangkan media pembelajaran dan mendeskripsikan kualitas media pembelajaran ditinjau dari aspek kevalidan, kepraktisan, dan keefektifan.

Pilar Baru merupakan aplikasi berbasis animasi yang berisi materi bangun ruang sisi datar, yaitu kubus, balok, prisma dan limas yang didesain dengan menarik dan mengoptimalkan teknologi digital yang disukai oleh siswa. Pilar Baru dibuat menggunakan aplikasi Adobe Flash CS6 dan software pendukung seperti Blender untuk animasi 3D dan Microsoft Word sebagai program pengolah kata. Terdapat 5 menu utama di dalam aplikasi seperti kompetensi, petunjuk, materi, evaluasi, dan profil yang diharapkan dapat membantu siswa dalam memahami materi bangun ruang sisi datar.

\section{KAJIAN PUSTAKA}

Media pembelajaran adalah segala sesuatu yang dapat menyampaikan dan menyalurkan pesan dari sumber secara terencana sehingga tercipta lingkungan belajar yang kondusif di mana penerimanya dapat melakukan proses belajar secara efisien dan efektif (Munadi, 2013). Sedangkan menurut Yaumi (2013) menjelaskan bahwa media pembelajaran adalah semua peralatan fisik, bahan, atau perangkat yang digunakan untuk memfasilitasi terciptanya efektivitas dan efisiensi belajar.

Multimedia interaktif adalah suatu multimedia yang dilengkapi dengan alat pengontrol yang dapat dioperasikan oleh pengguna, sehingga secara sengaja proses belajar terjadi, bertujuan dan terkendali. Munir (2012) menyatakan bahwa multimedia interaktif adalah suatu tampilan multimedia yang dirancang agar tampilannya memenuhi fungsi menginformasikan pesan dan memiliki interaktifitas dengan penggunanya. Pengertian ini merujuk pada kemampuan multimedia interaktif untuk berkomunikasi dengan penggunanya. Tampilannya dirancang agar pengguna dapat memperoleh informasi yang interaktif.

Penelitian pengembangan multimedia interaktif pada materi bangun ruang sisi datar telah dilakukan oleh Hendroanto (2012). Multimedia yang dikembangkan berupa bangun ruang 
berbasis $3 D$. Hasilnya menunjukkan bahwa media dinyatakan baik berdasarkan penilaian oleh para ahli. Sedangkan siswa dan guru memberikan respons yang sangat baik. Sehingga media yang dikembangkan layak untuk digunakan dalam proses pembelajaran.

Selain itu, Sassongko (2018) juga mengembangakan media pembelajaran multimedia interaktif "Petualangan Gatotkaca" pada materi bangun datar. Hasil penelitiannya menunjukkan bahwa media dinyatakan valid oleh dosen ahli materi dan ahli media maupun guru matematika. Respons guru mendapatkan kriteria baik dan respons guru mendapatkan kriteria sangat baik serta keterlaksanaan pembelajaran mendapatkan kriteria sangat baik sehingga media dinyatakan praktis. Sementara itu, persentase ketuntasan klasikal siswa sangat baik sehingga media dinyatakan efektif. Dengan demikian, media yang dikembangkan layak untuk digunakan dalam proses pembelajaran.

\section{METODE PENELITIAN}

Penelitian ini merupakan Research and Development (R\&D) dengan menggunakan model pengembangan ADDIE yang meliputi 5 tahapan yaitu analysis, design, development, implementation, dan evaluation. Subjek penelitian adalah peserta didik kelas VIII yang berjumlah 35 orang.

Instrumen penelitian yang digunakan dalam penelitian ini adalah (1) lembar penilaian media untuk mengukur kevalidan (2) angket respons guru dan siswa (3) lembar observasi keterlaksanaan pembelajaran (4) tes hasil belajar. Instrumen tersebut telah divalidasi oleh pakar Teknik pengumpulan data yang digunakan dalam penelitian ini adalah observasi, wawancara, angket, dan tes.

Teknik analisis data yang digunakan dalam penelitian ini adalah teknik analisis data kualitatif dan kuantitatif. Teknik analisis data secara kualitatif dilakukan dengan menganalisis hasil observasi awal. Data kualitatif ini yang dianalisis adalah berupa hasil observasi dan wawancara dengan guru matematika. Data ini digunakan sebagai bahan pertimbangan dalam mengembangkan media pembelajaran Pilar Baru. Teknik analisis data secara kuantitatif dilaksanakan melalui analisis validitas, analisis kepraktisan, dan analisis keefektifan.

\section{Analisis Kevalidan Media Pembelajaran}

Lembar penilaian yang digunakan berfungsi sebagai alat untuk mengukur kualitas kevalidan berupa kelengkapan dari isi, tujuan, format penulisan, bahasa, instruksional dan aspek teknis. Data hasil penilaian oleh pakar media, pakar materi dan guru dianalisis menggunakan persamaan 1.

Keterangan:

$$
\bar{x}=\frac{\sum_{i=1}^{n} x_{i}}{n}
$$

$$
\begin{array}{ll}
\bar{x} & =\text { rata-rata skor yang diperoleh } \\
\sum_{i=1}^{n} x_{i} & =\text { jumlah skor yang diperoleh ke- } i \\
n & =\text { banyaknya butir pertanyaan }
\end{array}
$$

Mengkonversikan skor rata-rata menjadi data kualitatif skala lima seperti pada Tabel 1. 
TABEL 1. Kriteria Kevalidan dan Kepraktisan Media Pembelajaran

\begin{tabular}{cl} 
Interval & \multicolumn{1}{c}{ Kriteria } \\
$x>4,2$ & Sangat baik \\
$\mathbf{3 , 4}<\boldsymbol{x} \leq \mathbf{4 , 2}$ & Baik \\
$\mathbf{2 , 6}<\boldsymbol{x} \leq \mathbf{3 , 4}$ & Cukup \\
$\mathbf{1 , 8}<\boldsymbol{x} \leq \mathbf{2 , 6}$ & Kurang \\
$\boldsymbol{x} \leq \mathbf{1 , 8}$ & Sangat Kurang \\
& \multicolumn{2}{c}{ Widoyoko (2009) }
\end{tabular}

\section{Analisis Kepraktisan Media Pembelajaran}

Instrumen angket respons guru dan siswa bertujuan untuk mengetahui kualitas kepraktisan berdasarkan tanggapan guru dan siswa terhadap manfaat dan kemudahan penggunaan media. Cara penilaian dilakukan dengan menghitung skor rata-rata menggunakan persamaan (1). Selanjutnya, skor rata-rata tersebut dikonversi menjadi data kualitatif skala lima merujuk pada Widoyoko (2009), seperti pada Tabel 1.

Kriteria penilaian keterlaksanaan pembelajaran disajikan pada Tabel 2.

TABEL 2. Kriteria Penilaian Keterlaksanaan Kegiatan Pembelajaran

\begin{tabular}{|c|c|}
\hline Rentang persentase & Kriteria \\
\hline $\boldsymbol{p} \geq \mathbf{9 0} \%$ & Sangat baik \\
\hline $\mathbf{8 0} \% \leq x<\mathbf{9 0} \%$ & Baik \\
\hline $\mathbf{7 0} \% \leq x<\mathbf{8 0} \%$ & Cukup \\
\hline $\boldsymbol{p}<\mathbf{8 0} \%$ & Kurang \\
\hline
\end{tabular}

\section{Analisis Keefektifan Media Pembelajaran}

Analisis keefektifan dilakukan menggunakan tes hasil belajar. Analisis dilakukan dengan menghitung nilai rata-rata siswa, kemudian menghitung jumlah siswa yang lulus KKM yaitu yang mendapatkan nilai lebih dari atau sama dengan 75 berdasarkan KKM sekolah dan yang terakhir memperesentase ketuntasan klasikal dengan rumus sebagai berikut:

$$
p=\frac{L}{n} \times 100 \%
$$

Dimana $p$ adalah persentase kelulusan siswa secara klasikal, $L$ adalah banyaknya siswa yang lulus KKM, dan $n$ adalah banyaknya siswa. Kemudian data dikonversi menjadi data kualitatif dengan menggunakan kriteria penilaian yang disajikan dalam Tabel 3.

TABEL 3. Kriteria Keefektifan Media Pembelajaran

\begin{tabular}{cl} 
Interval & \multicolumn{1}{c}{ Kriteria } \\
\hline $\boldsymbol{x}>\mathbf{4}, \mathbf{2}$ & Sangat baik \\
$\mathbf{3}, \mathbf{4}<\boldsymbol{x} \leq \mathbf{4 , 2}$ & Baik \\
$\mathbf{2}, \mathbf{6}<\boldsymbol{x} \leq \mathbf{3}, \mathbf{4}$ & Cukup \\
$\mathbf{1 , 8} \mathbf{8} \leq \mathbf{2 , 6}$ & Kurang \\
$\boldsymbol{x} \leq \mathbf{1 , 8}$ & Sangat Kurang \\
\hline & \multicolumn{2}{c}{ Widoyoko (2009) }
\end{tabular}




\section{HASIL DAN PEMBAHASAN}

Penelitian pengembangan ini menggunakan model pengembangan ADDIE, yang meliputi lima tahapan yaitu Analysis (Analisis), Design (Perencanaan), Development (Pengembangan), Implementation (Implementasi), dan Evaluation (Evaluasi). Berikut penjelasan tahapan-tahapan dalam penelitian pengembangan media pembelajaran multimedia interaktif Pilar Baru (Pintar Belajar Bangun Ruang) pada materi bangun ruang sisi datar untuk siswa SMP kelas VIII.

\section{Analisis}

\section{Analisis Karakteristik Siswa}

Analisis karakteristik siswa dapat diperoleh dari teori yang relevan, hasil observasi atau pengamatan saat pembelajaran berlangsung, dan wawancara terhadap guru matematika. Kajian teori perkembangan kognitif Jean Piaget (Sugihartono, 2012) mengatakan bahwa pada umumnya siswa SMP kelas VIII berada pada tahap keempat yaitu operasional formal. Tahap ini menandakan anak tidak lagi terbatas pada objek-objek yang konkret mulai dapat memikirkan kemungkinan yang akan terjadi, mengorganisasi masalah, berpikir secara konseptual dan logis.

Setelah observasi dilakukan, siswa sudah mampu memecahkan masalah dengan baik khususnya dalam konteks sehari-hari, namun diperlukan bantuan dari guru maupun media dalam kegiatan pembelajaran matematika guna mereka dapat memahaminya dengan baik. Siswa lebih mudah memahami materi yang bersifat nyata dan konkret terutama dalam konteks kehidupan seharihari. Peran guru masih sangat dibutuhkan guna membimbing siswa ketika siswa bingung memahami materi dengan baik. Sehngga dibutuhkan media pembelajarn yang menarik dan tidak membosankan.

\section{Analisis Situasi}

Setelah melakukan observasi, terdapat satu ruangan laboratorium komputer yang terdiri dari 21 unit komputer (sudah termasuk komputer server). Akan tetapi hanya 18 komputer client yang bisa dioperasikan dengan baik. Sehingga bisa mendukung pembelajaran berbasis multimedia. Spesifikasi komputer disajikan pada Tabel 4.

TABEL 4. Spesifikasi Komputer Lokasi Penelitian

\begin{tabular}{ccc}
\hline Spesifikasi Komputer & Komputer Server & Komputer Client \\
\hline Sistem Operasi & Windows 10 & Windows 10 \\
Prosesor & Intel Core i5 & Intel Core i3 \\
RAM & $8 \mathrm{~GB}$ & 4 GB \\
\hline
\end{tabular}

\section{Analisis Teknologi}

Setelah memikirkan dengan matang terhadap pendekatan dan materi dalam media pembelajaran yang akan dikembangkan maka ditentukan software utama pembuat media pembelajaran yaitu Adobe Flash CS6 dan beberapa software pendukung seperti Microsoft Word dan Blender. Adobe Flash CS6 merupakan sebuah software yang didesain khusus oleh Adobe dan program aplikasi standar authoring tool professional yang digunakan untuk membuat animasi dan bitmap yang sangat menarik untuk keperluan pembangunan situs web yang interaktif dan dinamis.

Adapun beberapa software pendukung dalam membuat media pembelajaran yaitu: (1) Microsoft Word 2013 yaitu software pengolah kata yang digunakan sebagai sarana untuk mengolah materi, contoh soal, latihan soal, dan soal tes hasil belajar. (2) Blender yaitu aplikasi pengobah gambar gerak atau animasi yang bisa diekspor menjadi GIF ataupun video yang digunakan untuk membuat animasi 3D dari kubus, balok, limas dan prisma. 


\section{Analisis Kurikulum}

Berdasarkan hasil pengamatan pelaksanaan pembelajaran matematika di kelas, diketahui kurikulum yang digunakan adalah Kurikulum 2013 (K13). Dimana K13 menuntut kegiatan pembelajaran berpusat pada siswa. Penyesuaian isi materi dalam media disesuaikan dengan buku dan mengarahkan siswa aktif dalam proses pembelajaran.

\section{Perancangan}

Dasar penyusunan rencana media pembelajaran multimedia interaktif matematika diambil dari hasil analisis tahap pertama. Pada tahap ini ada beberapa fase perencanaan diantarannya yaitu menyusun flowchart, menyusun storyboard, menyususn media pembelajaran, menyusun instrumen penelitian, menyusun materi dan soal, membuat Rencana Pelaksanaan Pembelajaran (RPP) beserta Lembar Kegiatan Peserta Didik (LKPD).

\section{Pengembangan}

Pada tahap pengembangan ini, merupakan realisasi dari seluruh rancangan baik itu flowchart, storyboard, materi yang dikembangkan menjadi media pembelajaran berupa multimedia interaktif matematika. Pengembangan multimedia interaktif menggunakan software utama Adobe Flash CS6 dan Microsoft Word dan Blender sebagai program pendukung.

\section{Pembuatan Media Pembelajaran}

Media pembelajaran yang dikembangkan memuat berbagai kegiatan yang dikelompokan dalam 5 pilihan menu utama, yaitu petunjuk, Standar Kompetensi dan Kompetensi Dasar (SK dan $\mathrm{KD}$ ), materi, latihan soal, dan profil. Berikut adalah bagian-bagian dari hasil pengembangan multimedia interaktif dengan software Adobe Flash CS6 yang disajikan dalam Gambar 1.
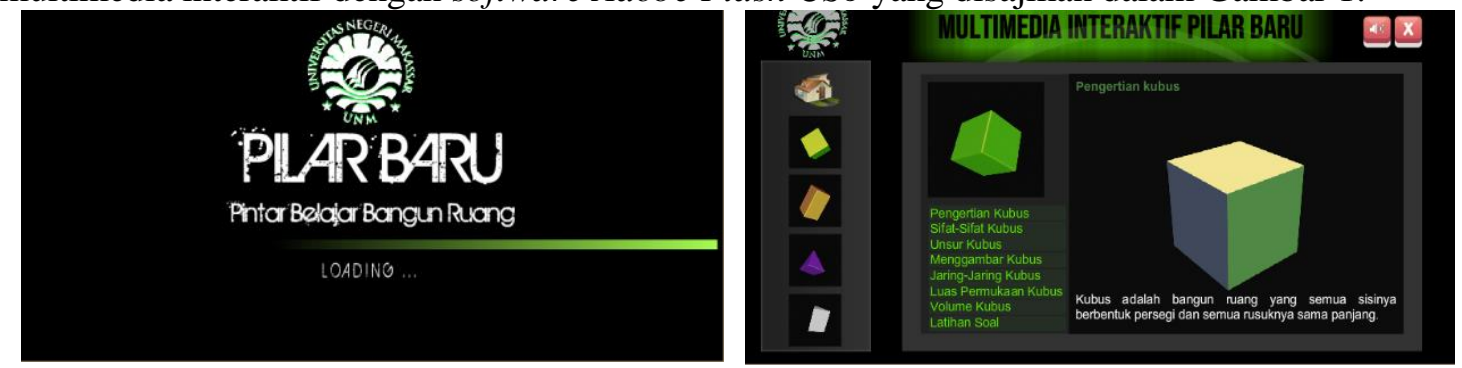

GAMBAR 1. Tampilan Pilar Baru

\section{Validitas Media Pembelajaran}

Produk media pembelajaran dikonsultasikan kepada dosen pembimbing sebelum divalidasikan ke dosen pakar materi, pakar media dan guru. Dari hasil konsultasi diperoleh beberapa masukan mengenai media pembelajaran Pilar Baru yaitu susunan menu pada beranda kurang tertata dan kurang adanya keterangan/deskripsi pada pilihan materi.

Penilaian media bertujuan untuk mengukur kualitas kevalidan media dan memperoleh masukan atau perbaikan terhadap media pembelajaran yang dikembangkan. Penilaian media juga bertujuan mengetahui kualitas isi, dan tujuan, format penulisan dan bahasa serta teknis media pembelajaran multimedia interaktif untuk diterapkan di sekolah. Berikut merupakan hasil validasi dari pakar materi, pakar media dan guru.

Data hasil penilaian media untuk pakar materi dan pakar media disajikan dalam Tabel 5. 
TABEL 5. Hasil Penilaian Media oleh Pakar Materi dan Pakar Media

\begin{tabular}{lcl}
\hline \multicolumn{1}{c}{ Aspek } & Rata-rata Skor & Kriteria \\
\hline Pakar Materi & & \\
Kualitas Isi dan Tujuan & 4,33 & Sangat Baik \\
Kualitas Intruksional & 4,22 & Sangat Baik \\
Pakar Media & & \\
Kualitas Teknis & 4,3 & Sangat Baik \\
\hline Rata-rata keseluruhan & 4,29 & Sangat Baik \\
\hline
\end{tabular}

Dari Tabel 5 menunjukkan bahwa media yang dikembangkan memiliki isi dan tujuan yang sesuai dengan tujuan pembelajaran. Media juga memberikan petunjuk atau arahan yang benar terhadap capaian belajar. Media yang dikembangkan memiliki tampilan yang menarik dari segi teks, gambar, maupun animasi.

Data hasil penilaian media oleh guru matematika media disajikan dalam Tabel 6.

TABEL 6 Hasil Penilaian Media oleh Guru Matematika

\begin{tabular}{lcc}
\hline \multicolumn{1}{c}{ Aspek } & Rata-rata Skor & Kriteria \\
\hline Kualitas Isi dan Tujuan & 4,4 & Sangat Baik \\
Kualitas Intruksional & 4,22 & Sangat Baik \\
Kualitas Teknis & 4,6 & Sangat Baik \\
\hline Rata-rata keseluruhan & 4,4 & Sangat Baik \\
\hline
\end{tabular}

Dari Tabel 6 menunjukkan bahwa media sudah dinyatakan valid berdasarkan penialain oleh pakar media, pakar materi dan guru matematika serta siap untuk diimplementasikan langsung di lapangan.

Terdapat beberapa perbaikan yang dilakukan berdasarkan saran dari pakar maupun dari guru matematika. Diantaranya pada menu latihan soal masih ada yang keliru karena tidak ada opsi jawaban yang benar. Pemilihan warna yang tidak sesuai antara intro, menu home, dengan menu materi. Selain itu, dilakukan perbaikan kalimat-kalimat pada materi yang masih belum memenuhi kaidah bahasa Indonesia yang baik dan benar.

\section{Implementasi}

Pada tahap implementasi, dilakukan uji coba media pembelajaran yang telah dikembangkan dan layak digunakan. Tahap ini meliputi uji coba media pembelajaran di kelas dan pemberian lembar observasi keterlaksanaan pembelajaran. Penjelasan masing-masing kegiatan sebagai berikut.

\section{Uji coba media pembelajaran}

Uji coba produk dilakukan terhadap siswa kelas VIII yang berjumlah 36 siswa dengan 1 unit laptop digunakan 4-6 siswa. Uji coba dilaksanakan selama empat kali pertemuan dan satu kali tes hasil belajar siswa untuk menilai keefektifan dari media pembelajaran yang dikembangkan.

\section{Pengamatan keterlaksanaan pembelajaran oleh observer}

Setiap penelitian perlu adanya pihak yang mengamati jalannya uji coba. Pada setiap uji coba yang dilakukan selalu didampingi oleh observer yang akan mencatat dan mengamati semua yang terjadi ketika pembelajaran. Data hasil analisis lembar observasi pembelajaran disajikan Tabel 7.

Berdasarkan Tabel 7 menunjukkan bahwa selama ujicoba media di dalam kelas berjalan dengan lancar pada pertemuan pertama, ketiga, dan keempat. Sedangkan pada pertemuan kedua tidak mencapai angka $100 \%$ dikarenakan ada masalah pada saat menginput password pada media. 
TABEL7. Rincian Kegiatan Pembelajaran dengan Media "Pilar Baru"

\begin{tabular}{lcc}
\hline \multicolumn{1}{c}{ Pertemuan } & Persentase & Kriteria \\
\hline Pertemuan pertama & $100 \%$ & Sangat Baik \\
Pertemuan kedua & $87,5 \%$ & Baik \\
Pertemuan ketiga & $100 \%$ & Sangat Baik \\
Pertemuan keempat & $100 \%$ & Sangat Baik \\
\hline Rata-rata keseluruhan & $96,87 \%$ & Sangat Baik \\
\hline
\end{tabular}

Pengisian angket respons guru dan siswa

Hasil dari analisis angket respons guru terhadap media pembelajaran Pilar Baru disajikan pada Tabel 8

TABEL 8. Hasil Analisis Angket Respons Guru

\begin{tabular}{|c|c|c|c|}
\hline \multicolumn{2}{|c|}{ Aspek } & \multirow{2}{*}{$\begin{array}{c}\begin{array}{c}\text { Rata-rata } \\
\text { Skor }\end{array} \\
4,33\end{array}$} & \multirow{2}{*}{$\begin{array}{c}\text { Kriteria } \\
\text { Sangat Baik }\end{array}$} \\
\hline Kualitas & Kejelasan & & \\
\hline dan Tujuan & Kepuasan & 5 & Sangat Baik \\
\hline Kualitas & Keingintahuan & 4,75 & Sangat Baik \\
\hline Intruksional & Semangat & 4 & Baik \\
\hline Kualitas & Kemudahan & 4,33 & Sangat Baik \\
\hline Teknis & Ketertarikan & 5 & Sangat Baik \\
\hline \multicolumn{2}{|c|}{ Rata-rata keseluruhan } & 4,57 & Sangat Baik \\
\hline
\end{tabular}

Dari Tabel 8 menunjukkan bahwa media menyampaikan tujuan dan materi bangun ruang dengan jelas serta memberikan kemudahan bagi guru dalam proses pembelajaran. Selain itu, media yang telah dikembangkan tidak membosankan selama proses pembelajaran berlangsung serta dapat menarik perhatian siswa untuk belajar matematika khususnya materi bangun ruang.

Hasil dari analisis angket respons siswa terhadap media pembelajaran Pilar Baru disajikan pada Tabel 9.

TABEL 9. Hasil Analisis Angket Respons Siswa

\begin{tabular}{|c|c|c|c|}
\hline \multicolumn{2}{|c|}{ Aspek } & \multirow{2}{*}{$\begin{array}{c}\text { Rata-rata } \\
\text { Skor } \\
4,63\end{array}$} & \multirow{2}{*}{$\begin{array}{c}\text { Kriteria } \\
\text { Sangat Baik }\end{array}$} \\
\hline Kualitas & Rasa Senang & & \\
\hline dan Tujuan & Minat & 4,67 & Sangat Baik \\
\hline Kualitas & Keaktifan & 4,56 & Sangat Baik \\
\hline Intruksional & Ketertarikan & 4,47 & Sangat Baik \\
\hline Kualitas & Kemudahan & 4,64 & Sangat Baik \\
\hline Teknis & Ketertarikan & 4,74 & Sangat Baik \\
\hline \multicolumn{2}{|c|}{ Rata-rata keseluruhan } & 4,62 & Sangat Baik \\
\hline
\end{tabular}

Tabel 9 menggambarkan bahwa selama proses pembelajaran menggunakan media, siswa bersungguh-sungguh dan merasa senang ketika belajar dengan bantuan media pembelajaran serta dapat membantu siswa dalam memahami materi dalam proses pembelajaran. Selain itu, media juga mendorong siswa untuk aktif dalam proses pembelajaran.

Hal ini menunjukkan bahwa kualitas media yang dikembangkan ditinjau dari kepraktisan memenuhi kualifikasi praktis berdasarkan keterlaksanaan pembelajaran, respons siswa dan respons guru.

\section{Evaluasi}

Evaluasi dilakukan di setiap tahapan pengembangan oleh dosen pembimbing. Evaluasi tersebut berupa masukan dan revisi dalam setiap tahap pengembangan. Evaluasi kualitas produk 
dilakukan oleh pakar materi dan pakar media pada tahap development (pengembangan), serta guru pada tahap implementation (implementasi). Selain itu juga dilakukan evaluasi apakah penggunaan media pembelajaran efektif atau tidak dengan dilaksanakannya tes hasil belajar. Hasil tes belajar siswa disajikan pada Tabel 10.

TABEL 10 Deskripsi Tes Hasil Belajar Siswa

\begin{tabular}{cc}
\hline Deskripsi & Kelompok Uji Coba \\
\hline Jumlah Subjek & 35 \\
Rata-rata nilai & 86,17 \\
Jumlah siswa yang tuntas & 28 \\
Jumlah siswa yang tidak tuntas & 7 \\
Persentase ketuntasan & $80,6 \%$ \\
Nilai maksimum & 100 \\
Nilai minimum & 50 \\
\hline
\end{tabular}

Ketuntasan berdasarkan KKM mata pelajaran matematika di SMP adalah 75. Siswa dikatakan tuntas apabila mendapat nilai $\geq 75$. Dari Tabel 10 menunjukkan bahwa media yang dikembangkan memberikan dampak positif bagi siswa dari segi hasil belajar. Sehingga media yang dikembangkan dinyatakan efektif dan bisa diapaki dalam proses pembelajaran matematika khususnya pada materi bangun ruang.

\section{KESIMPULAN}

Pengembangan media pembelajaran berupa multimedia interaktif "Pilar Baru (Pintar Belajar Bangun Ruang)" dilakukan dengan model ADDIE yang meliputi lima tahapan yaitu analysis, design, development, implementation, dan evaluation. Hasil penilaian media oleh para pakar diperoleh skor rata-rata sebesar 4,29 dengan kriteria sangat baik. Hasil penilaian media oleh guru diperoleh skor rata-rata sebesar 4,4 dengan kriteria sangat baik. Dengan demikian media dinyatakan valid.Data hasil angket respons guru diperoleh skor rata-rata 4,57 dengan kriteria sangat baik. Data hasil angket respons siswa diperoleh skor rata-rata 4,62 dengan kriteria sangat baik. Lembar observasi keterlaksanaan pembelajaran terhadap penggunaan media diperoleh persentase sebesar $97,25 \%$ dengan kriteria sangat baik. Dengan demikian media dinyatakan praktis. Persentase ketuntasan klasikal sebesar 80,6\% dengan kriteria sangat baik, sehingga media dinyatakan efektif.

Pengembangan media pembelajaran yang dilakukan telah memenuhi kualifikasi valid, praktis, dan efektif sehingga media sudah bisa digunakan di dalam kelas. Pada penelitian ini, pengembangan media masih terbatas pada satu materi yaitu geometri dengan pokok bahasan bangun ruang sisi datar sehingga perlu dilakukan pengembangan media pada materi yang lain.

\section{DAFTAR PUSTAKA}

Fahmi, S. (2014). Pengembangan Multimedia Macromedia Flash dengan Pendekatan Kontekstual dan Keefektifannya Terhadap Sikap Siswa pada Matematika. Jurnal AgriSains, 5(2).

Hendroanto, A. (2012). Pengembangan Media Pembelajaran Interaktif berbasis Animasi 3D dengan pendekatan kontekstual pada materi jaring-jaring dan luas bangun ruang sisi datar untuk siswa SMP kelas VIII. (Skripsi, tidak dipublikasikan) Universitas Negeri Yogyakarta, Yogyakarta.

Madja, MS. (1992). Perancangan dan Impelementasi Perangkat Ajar Geometri SMTA. (Tesis, tidak diterbitkan). Universitas Indonesia, Jakarta. 
Munadi, Y. (2013). Media Pembelajaran (Sebuah Pendekatan Baru). Jakarta: Gang Persada (GP) Press.

Munir. (2012). Multimedia (Konsep dan Aplikasi dalam Pendidikan). Bandung: Alfabeta.

Priliyanti. (2013). Pengembangan Media Pembelajaran Berbasis Multimedia Interaktif pada Materi Turunan Fungsi. Jurnal Ilmiah EdMathEdu, 2(2).

Sanusi, S., Suprapto, E., \& Apriandi, D. (2015). Pengembangan Multimedia Interaktif Sebagai Media Pembelajaran Pada Pokok Bahasan Dimensi Tiga di Sekolah Menengah Atas (SMA). JIPM (Jurnal Ilmiah Pendidikan Matematika), 3(2).

Sassongko, D. A. N. (2016). Pengembangan Media Pembelajaran Multimedia Interaktif "Petualangan Gatotkaca" Berbasis Pendekatan Kontekstual pada Materi Geometri untuk Siswa Kelas VII. (Skripsi, tidak dipublikasikan). Universitas Negeri Yogyakarta, Yogyakarta.

Sudjana, N. (2013). Penilaian Hasil Proses Belajar Mengajar. Bandung: PT Remaja Rosdakarya.

Sugihartono (2012). Psikologi Pendidikan. Yogyakarta: UNY Press.

Suwaji, Untung Trisna. (2008). Permasalahan Pembelajaran Geometri Ruang SMP dan Alternatif Pemecahannya. Yogyakarta: Pusat Pengembangan Permeberdayaan Pendidik dan Tenaga Kependidikan Matematika.

Widoyoko, E. P. (2009). Evaluasi Program Pembelajaran. Yogyakarta: Pustaka Pelajar.

Yaumi, M. (2013). Prinsip-Prinsip Desain Pembelajaran. Jakarta: Kencana Prenada Media Group. 